\title{
Evaluation of potential carryover effects associated with limit feeding of gravid Holstein heifers ${ }^{1}$
}

\author{
K. A. Kruse, ${ }^{*}$ D. K. Combs, ${ }^{*}$ N. M. Esser, ${ }^{*}$ W. K. Coblentz, $†$ and P. C. Hoffman ${ }^{* 2}$ \\ ${ }^{*}$ Department of Dairy Science, University of Wisconsin, Madison 53706 \\ †US Dairy Forage Research Center, Marshfield, WI 54449
}

\section{ABSTRACT}

Ninety-six Holstein heifers $(400 \pm 6 \mathrm{~kg}, 15.2 \pm 0.1$ mo), including 9 with ruminal cannulas, were offered 1 of 3 diets for $180 \pm 8 \mathrm{~d}$ in a randomized replicated pen design. Dietary treatments included a control diet (C100) and 2 independent limit-fed (LF) diets. The LF diets included one offered at $85 \%$ of $\mathrm{C} 100$ intake (L85) without an ionophore, and a second containing an ionophore $(325 \mathrm{mg} /$ head per day of lasalocid) that was offered at $80 \%$ of $\mathrm{C} 100$ intake $(\mathrm{L} 80+\mathrm{I})$. Heifers were evaluated for growth, rumen digesta volume, nutrient excretion, and subsequent lactation performance. Limit-fed heifers consumed less dry matter and neutral detergent fiber, and had greater respective average daily gains ( 0.96 or 0.89 vs. $0.81 \mathrm{~kg} / \mathrm{d})$, and lower feed:gain ratios (9.1 or 9.3 vs. $13.0 \mathrm{~kg} / \mathrm{kg}$ ) compared with heifers offered the $\mathrm{C} 100$ diet. No differences in rumen $\mathrm{pH}, \mathrm{NH}_{3}-$ $\mathrm{N}$, or volatile fatty acid concentrations were observed between C100 and LF heifers. Rumen digesta volume, density, and weight were unaffected by LF, and feeding L85 or L80+I did not result in carryover effects for rumen digesta volume when these heifers were offered a common high-fiber diet immediately after the 180-d growth trial. At parturition, no differences were observed for dystocia index, calf body weight, or 7-d postpartum body weight between cows offered LF or C100 diets as heifers. Lactation body weight, dry matter intake, and feed efficiency of cows did not differ between treatments at 45 or $90 \mathrm{~d}$ in milk. Milk yield and milk components also were not different between cows that were offered C100 or LF diets as gravid heifers. At $45 \mathrm{~d}$ in milk, rumen digesta volume was greater $(99.1$ vs. $66.1 \mathrm{~L})$ for cows offered L85 compared with cows offered L80+I as gravid heifers, but this effect was not observed at $90 \mathrm{~d}$ in milk. Limit feeding of gravid Holstein heifers for 180 $\mathrm{d}$ did not result in any carryover effects during their

\footnotetext{
Received May 4, 2010.

Accepted July 18, 2010.

${ }^{1}$ This research was conducted as a part of NC-1042, Management Systems to Improve the Economics and Environmental Sustainability of Dairy Enterprises.

${ }^{2}$ Corresponding author: pchoffma@wisc.edu
}

first lactation for rumen digesta volume, dry matter intake, or milk yield.

Key words: limit feeding, heifer, ionophore

\section{INTRODUCTION}

The primary goal of raising dairy replacement heifers is to reduce economic and environmental costs during the rearing period without compromising future lactation performance (Hoffman et al., 2007). Limit feeding $(\mathbf{L F})$ is a feeding management practice that has the potential to decrease feed usage, increase feed efficiency, and decrease manure excretion from dairy heifers (Hoffman et al., 2007; Zanton and Heinrichs, 2007). Increased feed efficiency in LF dairy heifers has been attributed to increased dietary DM digestibility (Zanton and Heinrichs, 2008, 2009) that results in a decrease in fecal output (Hoffman et al., 2007; Moody et al., 2007). Similar results have been reported for other ruminants, such as beef steers (Hicks et al., 1990), growing lambs (Susin et al., 1995), and beef heifers (Roberts et al., 2007). Limit feeding dairy heifers does not appear to alter ADG or skeletal growth of heifers during the growth phase when required nutrient intakes (Hoffman et al., 2007; Zanton and Heinrichs, 2007) are maintained.

The aforementioned research has generally focused on effects of LF dairy heifers during their growth phase. Equally important are the potential carryover effects of LF strategies on calving disorders, as well as rumen volume, DMI, and milk yield during first lactation. Hoffman et al. (2007) and Zanton and Heinrichs (2007) evaluated carryover effects of LF on milk yield and milk components and found no appreciable effects, but neither study made detailed measurements evaluating posttrial rumen volume or DMI during first lactation.

To date, LF management strategies for dairy heifers have not been demonstrated to alter heifer growth or milk production in the subsequent lactation, but detailed information regarding the mechanics of rumen capacity or effects on DMI during lactation that may be associated with previous LF management are weakly described. The objectives of this study were to examine effects of 2 LF strategies for gravid dairy heifers 
on subsequent manure excretion, rumen volume, and feed efficiency, and then to evaluate potential carryover effects of LF on DMI, rumen volume, and milk yield during first lactation.

\section{MATERIALS AND METHODS}

\section{Growth Phase}

Experimental Diets and Design. Ninety-six Holstein heifers $(400 \pm 6.1 \mathrm{~kg}, 15.2 \pm 0.10 \mathrm{mo})$, including 9 fit with ruminal cannulas, were offered 1 of 3 dietary treatments in a randomized, replicated-pen design. Heifers were stratified by BW and assigned to pens containing 8 heifers each. Pens were then assigned randomly to dietary treatments that included (1) a control diet (C100) offered to a defined bunk score; (2) an LF diet offered at $85 \%$ of C100 intake (L85); and (3) a second LF diet containing an ionophore (I, $325 \mathrm{mg} /$ head per day of lasalocid sodium; Alpharma, Elizabeth, NJ) and offered at $80 \%$ of $\mathrm{C} 100$ intake $(\mathbf{L} 80+\mathbf{I})$. The $\mathrm{C} 100$ diet was offered to a defined bunk score of 1 using a bunk scoring system where $0=$ no feed particles remaining; 1 $=$ scattered feed particles remaining; $2=$ abundant feed particles remaining, but concrete floor still visible; and 3 = feed completely covering the bottom of the bunk (Hoffman et al., 2008). The C100 diet was formulated based on NRC (2001) recommendations for a 450-kg heifer growing at $800 \mathrm{~g} / \mathrm{d}$ and contained $13.1 \% \mathrm{CP}$ and $2.1 \mathrm{Mcal} / \mathrm{kg}$ of ME. The L85 diet was formulated by replacing forage with shelled corn and soybean meal, thereby increasing the $\mathrm{CP}$ and $\mathrm{ME}$ contents of the diet to $15.5 \% \mathrm{CP}$ and $2.4 \mathrm{Mcal} / \mathrm{kg}$, respectively. The L85 diet was offered at $85 \%$ of $\mathrm{C} 100$ and designed to achieve isonitrogenous and isocaloric intakes. The L80+I diet contained the same nutrient density as L85, but was offered at $80 \%$ of $\mathrm{C} 100$. The $\mathrm{L} 80+\mathrm{I}$ was included in the experiment as a second LF strategy based on the work of Chester-Jones et al. (1997); in that study, supplementation of $>400-\mathrm{kg}$ dairy heifers with lasalocid sodium replaced approximately $0.64 \mathrm{~kg}$ of dietary total digestible nutrients. As a result, DMI was reduced by an additional $5 \%$ for the $\mathrm{L} 80+\mathrm{I}$ treatment. The $\mathrm{L} 80+\mathrm{I}$ diet was offered to increase statistical inference regarding the potential carryover effects associated with LF of gravid heifers following parturition. A description of ingredients and nutrient composition of the diets is presented in Table 1.

All animal handling procedures were approved by the Research Animal Resource Committee (RARC) of the University of Wisconsin-Madison. Heifers were housed in 4.5- $\times 9.0-\mathrm{m}$ pens in a 2-row, bedded-pack barn at the University of Wisconsin's Integrated Dairy Research facility (Marshfield, WI). Each pen comprised a feeding alley and a $30-\mathrm{m}^{2}$ group resting area $\left(3.8 \mathrm{~m}^{2} /\right.$ heifer) that was bedded 5 times/week with sawdust. Each heifer also had access to $0.56 \mathrm{~m}$ of bunk space at a neck-rail bunk line.

The L80+I base mix containing lasalocid sodium (Table 1) was mixed, and target drug levels were determined (Alpharma) before feeding. Treatment diets were offered once daily $(1100 \mathrm{~h})$ as a TMR for $180 \pm$ $8 \mathrm{~d}$. Feed was pushed up at approximately 2 and $4.5 \mathrm{~h}$ postfeeding. The amount of experimental diet offered to heifers assigned to the $\mathrm{L} 85$ and $\mathrm{L} 80+\mathrm{I}$ diets was adjusted daily based on pen intakes of heifers offered C100. Blended diets were sampled daily, composited on a weekly basis, subsampled, and then evaluated for DM concentration by drying under forced air for $48 \mathrm{~h}$ at $55^{\circ} \mathrm{C}$. Diet samples then were ground through a Wiley mill (Arthur H. Thomas, Philadelphia, PA) fitted with a 1-mm screen and saved for subsequent nutrient analysis. Orts were weighed and sampled daily, composited by week, and then analyzed for DM by the aforementioned procedure described for diet samples. Orts were negligible for heifers offered the L85 and L80+I diets. Daily refusals were converted to a DM basis and then subtracted from the daily dietary DM offered to ascertain the daily DMI for each pen.

Nutrient Excretion. After d $99 \pm 13$ of the growth trial, heifers were moved by pen to a dedicated collection pen bedded with $35 \mathrm{~kg}$ of fresh wood shavings distributed evenly throughout the resting area. Immediately following the distribution of the wood shavings, 5 randomly selected areas within the pen were sampled to ascertain the initial concentrations of DM, N, and P within the wood shavings. Composite samples, grouped from the 5 locations within each pen, were dried for $24 \mathrm{~h}$ at $55^{\circ} \mathrm{C}$ in a forced-air oven, ground through a Wiley mill fitted with a 1-mm screen, and then retained for subsequent nutrient analysis. Before each group of heifers was placed in the collection pen, the perimeter of the pen was bridged with $0.05-\times 0.20$-m boards to prevent cross-contamination of bedding and excretions between neighboring pens.

Following placement within the dedicated collection pen, heifers continued to receive their assigned treatment diets. After a 48-h collection period, all bedding, feces, and urine from the collection pen were transferred with a mechanical loader or manually shoveled into a $4.4-\mathrm{m}^{3}$ manure spreader (H\&S Manufacturing Company Inc., Marshfield, WI) that was equipped with electronic load cells (Digi-Star, Fort Atkinson, WI). Excreta and bedding were placed into the manure spreader, weighed, and vigorously mixed by the manure spreader and discharged onto a concrete pad. From this pile of mixed excreta and bedding, six 2- to $3-\mathrm{kg}$ samples were collected and then composited for nutri- 
Table 1. Ingredient and nutrient composition of growth and lactation phase diets

\begin{tabular}{|c|c|c|c|c|}
\hline \multirow[b]{2}{*}{ Item } & \multicolumn{3}{|c|}{ Growth phase $e^{1,2}$} & \multirow[b]{2}{*}{ Lactation } \\
\hline & C100 & L85 & L80+I & \\
\hline \multicolumn{5}{|l|}{ Ingredient } \\
\hline Corn silage & 21.0 & 14.8 & 14.8 & 29.4 \\
\hline Small grain silage & 25.9 & 14.7 & 14.7 & - \\
\hline Alfalfa silage & 44.4 & 35.8 & 35.8 & 33.6 \\
\hline Shelled corn & 1.6 & 18.5 & 18.5 & - \\
\hline Soybean meal & 2.2 & 10.5 & 10.5 & - \\
\hline Alfalfa hay & - & - & - & 3.4 \\
\hline Base $\operatorname{mix}^{3,4}$ & 5.0 & 5.8 & 5.8 & 33.9 \\
\hline \multicolumn{5}{|l|}{ Nutrient composition } \\
\hline DM & 40.3 & 47.4 & 47.4 & 49.0 \\
\hline $\mathrm{CP}$ & 13.1 & 15.5 & 15.5 & 18.3 \\
\hline $\mathrm{NDF}$ & 49.1 & 36.5 & 36.5 & 33.0 \\
\hline IV NDFD, ${ }^{5} \% \mathrm{NDF}$ & 51.4 & 53.1 & 53.1 & 54.8 \\
\hline NFC & 29.3 & 39.7 & 39.7 & 34.8 \\
\hline Ether extract & 2.3 & 2.5 & 2.5 & 4.0 \\
\hline $\mathrm{P}$ & 0.30 & 0.35 & 0.35 & 0.45 \\
\hline $\mathrm{Ca}$ & 0.70 & 0.75 & 0.75 & 0.95 \\
\hline $\mathrm{K}$ & 2.1 & 1.8 & 1.8 & 1.6 \\
\hline $\mathrm{Mg}$ & 0.3 & 0.3 & 0.3 & 0.4 \\
\hline Ash & 9.1 & 8.5 & 8.5 & 9.6 \\
\hline \multicolumn{5}{|l|}{ Energy calculations ${ }^{6}$} \\
\hline TDN & 56.5 & 65.0 & 65.0 & 67.8 \\
\hline ME, Mcal/kg & 2.1 & 2.4 & 2.4 & 2.6 \\
\hline $\mathrm{NE}_{\mathrm{G}}, \mathrm{Mcal} / \mathrm{kg}$ & 0.65 & 0.96 & 0.96 & 1.5 \\
\hline $\mathrm{NE}_{\mathrm{M}}, \mathrm{Mcal} / \mathrm{kg}$ & 1.2 & 1.6 & 1.6 & 1.7 \\
\hline \multicolumn{5}{|c|}{$\begin{array}{l}{ }^{1} \mathrm{C} 100=\text { control diet; } \mathrm{L} 85=\text { limited to } 85 \% \text { of } \mathrm{C} 100 ; \mathrm{L} 80+\mathrm{I}=\text { limited to } 80 \% \text { of } \mathrm{C} 100+325 \mathrm{mg} / \mathrm{d} \text { of lasal- } \\
\text { ocid. }\end{array}$} \\
\hline \multicolumn{5}{|c|}{${ }^{2}$ All ingredients and nutrients are expressed on a percentage DM basis unless otherwise specified. } \\
\hline \multicolumn{5}{|c|}{$\begin{array}{l}{ }^{3} \mathrm{Growth}-\mathrm{phase} \text { base mix contained ground shelled corn and } 726 \mathrm{IU} / \mathrm{kg} \text { of vitamin A, } 244 \mathrm{IU} / \mathrm{kg} \text { of vitamin D, } \\
89 \mathrm{mg} / \mathrm{kg} \text { of } \mathrm{Zn}, 67 \mathrm{mg} / \mathrm{kg} \text { of } \mathrm{Mn}, 45.1 \mathrm{mg} / \mathrm{kg} \text { of } \mathrm{Cu}, 1.3 \mathrm{mg} / \mathrm{kg} \text { of I, and } 0.6 \mathrm{mg} / \mathrm{kg} \text { of Co. }\end{array}$} \\
\hline \multicolumn{5}{|c|}{$\begin{array}{l}{ }^{4} \text { Feed ingredients in the lactation base mix were ground shelled corn, cottonseed, soybean meal, and a mineral- } \\
\text { vitamin premix that contained 1,181,400 IU of vitamin A, 391,600 IU } / \mathrm{kg} \text { of vitamin D, } 9,790 \mathrm{IU} / \mathrm{kg} \text { vitamin } \\
\mathrm{E}, 1.4 \% \mathrm{Ca}, 0.1 \% \mathrm{P}, 0.06 \% \mathrm{~K} \text {, and } 64 \mathrm{mg} / \mathrm{kg} \text { of Se. }\end{array}$} \\
\hline \multicolumn{5}{|c|}{${ }^{5}$ In vitro NDF digestibility after 48 -h incubation. } \\
\hline${ }^{6}$ Calculated per NRC & . & & & \\
\hline
\end{tabular}

ent analysis. Concentrations of $\mathrm{N}$ retained in the soiled bedding were derived before drying according to AOAC (1990) methods. Nitrogen volatilization during the 48-h collection period could not be determined (Varel et al., 1999); therefore, $\mathrm{N}$ excretion data are comparative only. The remaining portion of each excreta or bedding sample was dried at $55^{\circ} \mathrm{C}$ for $48 \mathrm{~h}$, ground through a Wiley mill fitted with a 1-mm screen, and retained for subsequent analysis of $\mathrm{P}$.

Commencing $2 \mathrm{~d}$ before nutrient excretion collection and continuing through the nutrient excretion collection period, blended diets were sampled daily, dried at $55^{\circ} \mathrm{C}$ for $48 \mathrm{~h}$, ground through a Wiley mill fitted with a 1-mm screen, composited over days, and then retained for subsequent analysis of $\mathrm{N}$ and $\mathrm{P}$.

Body and Blood Measurements. Frame and BW measurements of the heifers were recorded on 2 consecutive days (immediately before feeding) at initiation and termination of the growth trial. Heifers were weighed using a cattle chute (Real Tuff, Clearbrook, MN) fitted with an electronic scale (Tru-Test Inc., Mineral Wells,
TX). Frame measurements included hip height, heart girth, and body length using the methods of Esser et al. (2009), and BCS, which was evaluated by the system of Wildman et al. (1982).

On d 66 and 132 of the growth trial, blood samples were collected into blood serum-separator tubes (BD Vacutainer, Franklin Lakes, NJ) from the jugular vein of each heifer at approximately $3 \mathrm{~h}$ postfeeding. After collection, blood samples were immediately cooled and centrifuged at $1,074 \times g$ for $20 \mathrm{~min}$. Blood serum was evaluated for glucose, alkaline phosphatase, total protein, albumin, BUN, Ca, and P by Marshfield Laboratories (Marshfield, WI).

Rumen Measurements. Three pen replications assigned to C100, L85, and L80+I diets each contained 1 heifer $(\mathrm{n}=9)$ fitted with a ruminal cannula. On d 66 and 132 of the growth trial, rumen fluid was obtained from 5 randomly selected areas of the rumen to obtain a representative sample. Rumen fluid was collected with a hand-siphon pump (Gempler's, Madison, WI) for 2 consecutive days at $-1,1,3,6,9,12$, and $18 \mathrm{~h}$ 
postfeeding. An aliquot of rumen fluid was measured for $\mathrm{pH}$ (Horiba Twin pH B213, Spectrum Technologies, Plainfield, IL) immediately after collection. Remaining rumen fluid was filtered through 2 layers of cheesecloth, and then $1 \mathrm{~mL}$ of rumen fluid was pipetted into a vial containing $0.02 \mathrm{~mL}$ of $50 \%$ TCA for subsequent determination of ruminal $\mathrm{NH}_{3}-\mathrm{N}$ as described by Sievert and Shaver (1993). Similarly, $1 \mathrm{~mL}$ of rumen fluid was added to $0.12 \mathrm{~mL}$ of $50 \% \mathrm{H}_{2} \mathrm{SO}_{4}$ and retained in sealed vials at $-20^{\circ} \mathrm{C}$ for analysis of VFA by gas chromatography (Bal et al., 2000).

To determine potential differences in digesta volume, density, and weight that were induced by LF, rumen evacuations were conducted $-14,-7,+7$, and $+14 \mathrm{~d}$ relative to the termination date of the growth trial. Fourteen and $7 \mathrm{~d}$ before the growth trial was terminated, digesta volume, density, and weight were determined from cannulated heifers assigned to each treatment (C100, L85, or L80+I) group. Upon termination of the growth trial, all heifers in the pen, including cannulated heifers, were switched to a common high-NDF diet (C100; Table 1). Posttrial rumen evacuations also were conducted 7 and $14 \mathrm{~d}$ after introduction of the common C100 diet to ascertain if there were immediate carryover effects of LF on rumen volume. Rumens were emptied $3 \mathrm{~h}$ postfeeding, with rumen fluid and digesta placed into preweighed 100-L plastic trashcans. Rumen digesta were weighed, and the level was marked on the outside of the plastic trashcan. After returning digesta to each cannulated heifer, water was added to each trashcan up to the previously marked digesta level; this volume of water was then measured and weighed. The volume and density of the rumen contents for each cannulated heifer was then calculated using a density of water conversion as described by Johnson and Combs (1991). Rumen contents were mixed and subsampled, and their DM concentrations were determined by drying at $55^{\circ} \mathrm{C}$ in a forced air oven for $72 \mathrm{~h}$.

Feed and Manure Analysis. Diet samples were evaluated for CP, fat, and ash (AOAC, 1990), as well as ADF and NDF by the methods of Goering and Van Soest (1970) with modifications described by Mertens (1992). Concentrations of $\mathrm{N}$ in NDF, expressed on a CP basis (NDICP), were ascertained by refluxing diet samples in neutral detergent using the aforementioned procedures, and then determining the residual $\mathrm{CP}$ concentration within these NDF residues with a macroKjeldahl technique (AOAC, 1990). No sodium sulfite was used in the NDF procedure to avoid removal of CP from the NDF residues (Van Soest et al., 1991). Determination of NDICP was used only to facilitate the summative calculation of energy density (NRC, 2001), and NDICP data are not presented. Calcium, K, and $\mathrm{Mg}$ were determined by atomic absorption spectros- copy and $\mathrm{P}$ by the colorimetric methods (Schulte et al., 1987).

The in vitro NDF digestibility of diet samples (IV NDFD, \% of NDF) were determined by a modified procedure of Goering and Van Soest (1970). Basic in vitro procedures and apparatus consisted of incubating $0.5 \mathrm{~g}$ of dried, ground sample in a $\mathrm{CO}_{2}$ back-pressured 125-mL Erlenmeyer flask containing rumen fluid, buffer media, macromineral, and micromineral solutions for $48 \mathrm{~h}$. Flasks were incubated in a water bath maintained at $39^{\circ} \mathrm{C}$. Rumen fluid was harvested from a nonlactating dairy cow fit with a ruminal cannula and offered a diet containing $59 \%$ alfalfa-grass silage, $40 \%$ corn silage with the balance of the diet consisting of vitamins and mineral supplements. Rumen fluid was held at $39^{\circ} \mathrm{C}$ in $\mathrm{CO}_{2}$-gassed vessels, mixed in a $\mathrm{CO}_{2}$-gassed blender, and strained through 3 layers of cheesecloth before injection into the incubation flask. The 48 -h incubations were terminated by digestion in neutral detergent (Goering and Van Soest, 1970; Mertens, 1992), thereby yielding indigestible NDF. The IV NDFD (\% of NDF) and was used to estimate truly digestible fiber within the summative approach to calculate the energy content of ruminant feedstuffs described in NRC (2001).

The DM, N, and $\mathrm{P}$ concentrations of fresh wood shavings, as well as mixed pen-manure samples (urine, feces, and bedding) were determined by aforementioned laboratory methods. Concentrations of $\mathrm{N}$ from penmanure collections were determined without drying at $55^{\circ} \mathrm{C}$ to minimize $\mathrm{N}$ volatilization. Excretions of DM, $\mathrm{N}$, and $\mathrm{P}$ were calculated by subtracting the amount of $\mathrm{DM}, \mathrm{N}$, and $\mathrm{P}$ in the fresh wood shavings from that in the pen collections.

\section{Lactation Phase}

Housing, Management, and Lactation Diet. Approximately $42 \mathrm{~d}$ before their expected calving date, heifers were transported from Marshfield to Arlington, Wisconsin. Prior to calving, heifers were placed in a loose-housing facility bedded with straw and offered a standard prepartum ration (87:13 forage:concentrate) until parturition. The prepartum ration was not sampled or evaluated for nutrient content. At parturition, calf BW and sex, dystocia index (Hoffman et al., 2007), and a 7-d postpartum BW were recorded. Subsequently, a postpartum diet was offered once daily as a TMR and balanced according to NRC (2001) recommendations for 550-kg primiparous cow yielding $40 \mathrm{~kg}$ of milk with $3.70 \%$ fat and $3.0 \%$ protein (Table 1 ).

The DMI and lactation performance of primiparous cows previously offered the C100 or LF diets as heifers were measured during 2 data-collection periods at $45 \pm$ 3.9 and $90 \pm 5.5$ DIM. When individual cows reached 
45 or 90 DIM, each cow was housed in an individual stanchion, where a 2 -d adaptation period followed by 5 -d collection was employed to measure DMI. The blended diet was offered daily at rates designed to result in refusals of approximately 5\%. The postpartum diet was sampled daily during the lactation-collection period. Daily diet samples were dried at $60^{\circ} \mathrm{C}$ for $48 \mathrm{~h}$, and then composited by week. Orts were subtracted from the amount of DM offered to ascertain DMI, but orts were not analyzed chemically. Weekly composite samples of the lactation-phase diet were ground through a Wiley mill fitted with a 1-mm screen. Weekly dried ground samples were composited by month and analyzed for CP, NDF, and NDICP by the methods described previously for the growth phase.

On d 3 and 4 of the collection periods, BW and BCS (Wildman et al., 1982) of the cows were recorded. Cows were milked in double- 8 herringbone parlor, and milk yield was measured using calibrated weigh jars. Milk was sampled for 6 consecutive milking periods using an autosampler and placed into 50-mL milk vials containing milk preservative. Milk was analyzed for fat, true protein, SNF, and lactose by near infrared spectroscopy (Ag Source, Menomonie, WI).

The 9 cannulated heifers used in the growth phase of the experiment transitioned into lactation without calving or metabolic problems. Rumen evacuation procedures identical to those used in the growth phase were conducted on these primiparous cows at 45 and 90 DIM on d 4 of each collection period to evaluate potential lactation carryover effects of LF on 3-h postfeeding rumen digesta volume, weight, and density.

Animal Health and Culling. During the growth trial, 1 heifer was removed from the experiment because of a lost pregnancy. Upon completion of the growth trial, 2 heifers were culled because of reproductive failure, and 2 additional heifers were culled as a result of neosporosis. During lactation, 3 cows were culled for bovine herpes mammillitis and 1 cow was euthanized due to difficult calving. Lactation data from 5 cows were not collected because of time constraints; therefore, 82 heifers fully completed the lactation phase of the experiment.

\section{Statistics}

Body, blood, nutrient intake and excretion data during the growth phase were analyzed using the PROC MIXED procedure of SAS (SAS Institute, 2003) with pens as replications (experimental units) using penbased statistical models described by St-Pierre (2007). The model included the fixed effect of treatment and the random effects of pen and pen nested within treatment.
Rumen VFA and $\mathrm{NH}_{3}-\mathrm{N}$ data from growth phase of the experiment and rumen digesta volume, density, and weight data from the growth and lactation phase of the experiment were evaluated as split-plot using the PROC MIXED procedure of SAS. The model used the individual cannulated heifer as the experimental unit and included fixed effects (treatment and treatment $x$ time) and random effects [heifer, heifer nested within treatment, and time (h or collection day)]. To account for correlated errors on the experimental unit, a firstorder autoregressive (AR1) error structure was applied to rumen volume, density, and weight data. All lactation phase data (DMI, milk yield, milk components, $\mathrm{BW}, \mathrm{BCS}$, calf BW, and calving dystocia index) were averaged into pen within treatment means, and the pen assigned in the growth trial was maintained as the experimental unit for lactation phase data. Lactation phase data were evaluated using the same statistical model as listed above for growth phase body, blood, nutrient intake, and excretion data as defined by StPierre (2007). Preplanned contrasts (C100 vs. LF and L85 vs. L80+I) were made with significance declared when $P<0.05$.

\section{RESULTS AND DISCUSSION}

\section{Growth Phase}

Nutrient Intakes. The effect of LF strategies on nutrient and energy intake by gravid Holstein replacement heifers is presented in Table 2. As designed, heifers offered the $\mathrm{C} 100$ diet consumed more $(P<0.01) \mathrm{DM}$ than heifers offered LF diets; these differentials were 1.8 and $2.2 \mathrm{~kg} / \mathrm{d}$ for L85 and L80+I diets, respectively. Intakes were not isonitrogenous across feeding strategies. All treatment diets supplied $>1,200 \mathrm{~g}$ of $\mathrm{CP} / \mathrm{d}$, but heifers offered the L85 and L80+I diets consumed 100 and $200 \mathrm{~g}$ less $\mathrm{CP} / \mathrm{d}$ than heifers offered the C100 $\operatorname{diet}(P=0.02)$. The estimated dietary requirement for a 450-kg Holstein heifer with a target gain of $800 \mathrm{~g} / \mathrm{d}$ is $1,088 \mathrm{~g} / \mathrm{d}$ of $\mathrm{CP}$, with a calculated MP requirement of approximately $635 \mathrm{~g} / \mathrm{d}$ (NRC, 2001). The mean MP supplied across all diets was $915 \mathrm{~g} / \mathrm{d}$ (data not shown), suggesting that the $\mathrm{CP}$ and MP supplies provided by all diets were adequate.

Intake of NDF by heifers decreased $(P<0.01)$ with LF because of the decreasing proportion of forages in LF diets. Heifers offered the $\mathrm{C} 100$ diet consumed more $(P<0.01)$ digestible NDF $(\mathrm{kg} / \mathrm{d})$ than heifers offered the LF diets simply because C100 contained more forage NDF. Intakes of NFC did not differ $(P \geq 0.37)$ across dietary treatments because the greater concentrations of NFC in LF diets (Table 1) were offset by the concurrent restriction of DMI in these same diets. 
Table 2. Effect of limit feeding on nutrient intake and excretion of growing Holstein replacement heifers

\begin{tabular}{|c|c|c|c|c|c|c|}
\hline Item & \multicolumn{3}{|c|}{ Treatment $^{1}$} & SEM & \multicolumn{2}{|c|}{ Effect $(P>\mathrm{F})$} \\
\hline & & $-\mathrm{Gr}$ & lase - & 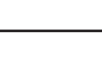 & & \\
\hline \multicolumn{7}{|l|}{ Nutrient intake } \\
\hline $\mathrm{DM}, \mathrm{kg} / \mathrm{d}$ & 10.3 & 8.5 & 8.1 & 0.21 & $<0.01$ & 0.18 \\
\hline $\mathrm{CP}, \mathrm{kg} / \mathrm{d}$ & 1.4 & 1.3 & 1.2 & 0.02 & 0.03 & 0.05 \\
\hline $\mathrm{NDF}, \mathrm{kg} / \mathrm{d}$ & 5.1 & 3.1 & 2.9 & 0.11 & $<0.01$ & 0.25 \\
\hline Fat, $\mathrm{kg} / \mathrm{d}$ & 0.24 & 0.21 & 0.21 & 0.011 & 0.03 & 0.51 \\
\hline Ash, $\mathrm{kg} / \mathrm{d}$ & 0.94 & 0.72 & 0.68 & 0.032 & $<0.01$ & 0.30 \\
\hline $\mathrm{P}, \mathrm{g} / \mathrm{d}$ & 30.6 & 30.6 & 26.1 & 1.13 & 0.14 & 0.02 \\
\hline $\mathrm{Ca}, \mathrm{g} / \mathrm{d}$ & 71.5 & 63.6 & 63.6 & 4.51 & 0.18 & 1.00 \\
\hline $\mathrm{K}, \mathrm{g} / \mathrm{d}$ & 203 & 152 & 142 & 11.2 & $<0.01$ & 0.54 \\
\hline $\mathrm{Mg}, \mathrm{g} / \mathrm{d}$ & 26.1 & 20.4 & 20.4 & 1.72 & 0.02 & 1.00 \\
\hline \multicolumn{7}{|l|}{ Energy intake ${ }^{4}$} \\
\hline \multicolumn{7}{|l|}{ Nutrient intake ${ }^{5}$} \\
\hline $\mathrm{DM}, \mathrm{kg} / \mathrm{d}$ & 9.9 & 9.4 & 8.4 & 0.32 & 0.03 & 0.06 \\
\hline $\mathrm{N}, \mathrm{g} / \mathrm{d}$ & 200 & 243 & 221 & 6.9 & $<0.01$ & 0.06 \\
\hline $\mathrm{P}, \mathrm{g} / \mathrm{d}$ & 29.5 & 32.9 & 28.4 & 7.72 & 0.08 & 0.58 \\
\hline \multicolumn{7}{|l|}{ Nutrient excretion } \\
\hline $\mathrm{DM}, \mathrm{kg} / \mathrm{d}$ & 4.3 & 3.9 & 3.2 & 0.37 & 0.15 & 0.24 \\
\hline $\mathrm{N}, \mathrm{g} / \mathrm{d}$ & 122 & 161 & 121 & 10.4 & 0.19 & 0.04 \\
\hline$P, g / d$ & 21.6 & 26.1 & 23.8 & 1.63 & 0.11 & 0.33 \\
\hline
\end{tabular}

${ }^{1} \mathrm{C} 100=$ control diet; $\mathrm{L} 85=$ limited to $85 \%$ of $\mathrm{C} 100 ; \mathrm{L} 80+\mathrm{I}=$ limited to $80 \%$ of $\mathrm{C} 100+325 \mathrm{mg} / \mathrm{d}$ of lasalocid.

${ }^{2} \mathrm{C}=$ control $(\mathrm{C} 100)$ vs. $\mathrm{LF}=$ limit fed $(\mathrm{L} 85$ and $\mathrm{L} 80+\mathrm{I})$ diets.

${ }^{3}$ In vitro digestible NDF as determined by a 48 -h incubation.

${ }^{4}$ Calculated per NRC (2001); TDN = total digestible nutrients.

${ }^{5}$ Nutrient intakes during the fecal collection periods.

Intakes of $\mathrm{Ca}$ and $\mathrm{P}$ were not different $(P \geq 0.14)$ between $\mathrm{C} 100$ and LF heifers, but ash, $\mathrm{K}$, and Mg intakes were greater $(P \leq 0.02)$ for heifers offered the $\mathrm{C} 100$ diet compared with LF diets, largely because of nuances in treatment diet forage:concentrate ratios and differing DMI. Intakes of energy, expressed as TDN, ME, $\mathrm{NE}_{\mathrm{G}}$ or $\mathrm{NE}_{\mathrm{M}}$, were not different $(P \geq 0.10)$ across dietary treatments, which met the pretrial objective of providing isocaloric intakes across treatment groups.

Nutrient Excretion. The effects of LF strategies on fecal nutrient excretions of gravid Holstein replacement heifers are also presented in Table 2. Actual nutrient intakes during the manure collection differed slightly from overall growth phase means (Table 2), but the DMI for heifers offered C100 diet remained greater $(P$ $=0.03)$ than that of heifers offered LF diets. Excretion of DM did not differ $(P=0.15)$ between $\mathrm{C} 100$ and LF heifers and no reduction $(P=0.24)$ of manure DM excreted was observed in heifers offered $\mathrm{L} 80+\mathrm{I}$ diets compared with heifers offered L85. Reductions in DM excretion are commonly observed in studies evaluating LF feeding strategies (Sip and Pritchard, 1991; Mur- phy et al., 1994; Hoffman et al., 2007). The numerical decreases in DM excretion by LF heifers without a significant statistical inference may have been the result of pen-based fecal collection procedures.

In contrast to that in the growth phase of the experiment, $\mathrm{N}$ intake was greater $(P<0.01)$ during the manure collection periods for heifers offered L85 and L80+I diets compared with those offered the C100 diet. There tended $(P=0.06)$ to be a difference between $\mathrm{N}$ intake between the L85 $(243 \mathrm{~g} / \mathrm{d})$ and L80+I $(221 \mathrm{~g} / \mathrm{d})$ diets. Heifers offered L85 and L80+I diets consumed 43 and $21 \mathrm{~g} / \mathrm{d}$ more $\mathrm{N}$, respectively, than heifers offered C100 diets, but no difference $(P=0.19)$ in actual $\mathrm{N}$ excretion between heifers offered C100 and LF diets was observed. Moody et al. (2007) reported that N digestibility was not different for LF heifers consuming diets containing greater levels of concentrate compared with heifers offered high corn silage diets for ad libitum intake. They concluded that N-retention efficiency is optimized when heifers are offered diets that meet $\mathrm{CP}$ requirements. Excretion of $\mathrm{P}$ ranged from 21.6 to 26.1 $\mathrm{g} / \mathrm{d}$ and was not different $(P \geq 0.11)$ between heifers 
Table 3. Effects of limit feeding on body size and growth of Holstein replacement heifers

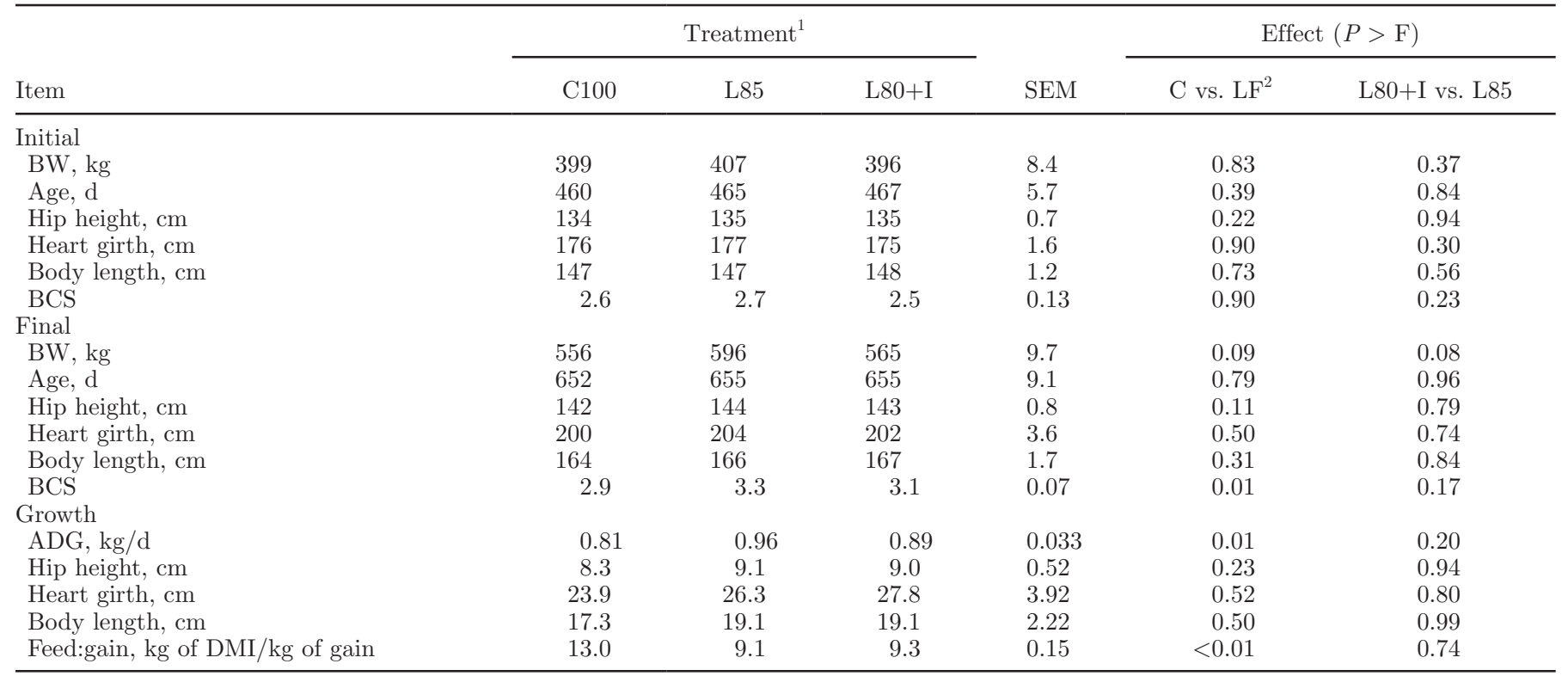

${ }^{1} \mathrm{C} 100=$ control diet; $\mathrm{L} 85=$ limited to $85 \%$ of $\mathrm{C} 100 ; \mathrm{L} 80+\mathrm{I}=$ limited to $80 \%$ of $\mathrm{C} 100+325 \mathrm{mg} / \mathrm{d}$ of lasalocid.

${ }^{2} \mathrm{C}=$ control $(\mathrm{C} 100)$ vs. $\mathrm{LF}=$ limit fed $(\mathrm{L} 85$ and $\mathrm{L} 80+\mathrm{I})$ diets.

offered LF or C100. Data support the previous work of Hoffman et al. (2007) who observed that LF had little influence on P excretion or retention.

Body Size and Growth. The effects of LF on body size and growth of heifers are presented in Table 3. Initial BW, age, hip height, heart girth, body length, and BCS were similar $(P \geq 0.22)$ for heifers offered each treatment diet. Final BW tended to be greater for heifers offered LF diets compared with the $\mathrm{C} 100$ diet $(P=0.09)$. However, this advantage for LF strategies was largely associated with the L85 diet, which tended to support a greater final BW than the L80+I diet (596 vs. $565 \mathrm{~kg} ; P=0.08)$. Although the ending BW tended to be greater for LF heifers, no measurement of frame size was affected $(P \geq 0.11)$.

The ADG was greater $(P=0.01)$ for LF heifers compared with heifers offered the C100 diet. No difference $(P=0.20)$ in ADG was observed between heifers offered L85 or L80+I diets, suggesting that the combination of additional feed restriction and ionophore supplementation was effective at maintaining ADG. Increased ADG combined with decreased DMI resulted in an improved $(P<0.01)$ feed:gain ratio for LF heifers, relative to those offered the $\mathrm{C} 100$ diet, but efficiencies between LF diets did not differ $(P=0.74)$. Overall, feed:gain ratio was improved by an average of $29.2 \%$ by LF. Previous work has demonstrated that reduced feed intake (Hoffman et al., 2007) is often associated with increased rumen retention time (Lascano and Heinrichs, 2009), resulting in increased diet digestibility (Moody et al., 2007) and decreased visceral mass (Reynolds et al.,
1991). These interrelated factors work collectively to improve feed:gain ratios for LF heifers. Ending BCS differed between heifers offered LF and C100 diets (3.2 vs. $2.9 ; P=0.01$ ), but no differences were observed between the $2 \mathrm{LF}$ strategies $(P=0.17)$. The increase in BCS and trends of increased BW without alteration of frame size suggests that LF heifers gained more adipose tissue than those offered the $\mathrm{C} 100$ diet.

Blood Metabolites. The effects of LF strategies on concentrations of blood metabolites are presented in Table 4. Heifers consuming LF diets had greater $(P$ $=0.03)$ blood glucose levels (mean $=74 \mathrm{mg} / \mathrm{dL}$ ) than heifers offered the $\mathrm{C} 100$ diet $(68 \mathrm{mg} / \mathrm{dL})$. Because blood was evaluated at $3 \mathrm{~h}$ postfeeding, the greater concentration of blood glucose may be a postfeeding artifact of more rapid DMI of heifers fed LF diets because total NFC intakes did not differ. The blood glucose concentrations of heifers offered L80+I diets did not differ $(P$ $=0.50)$ from those of heifers offered L85. Blood alkaline phosphatase, total protein, albumin, BUN, $\mathrm{P}$, and $\mathrm{Ca}$ were not affected by LF $(P \geq 0.14)$, and no difference $(P \geq 0.35)$ was observed between LF strategies for any blood metabolite.

Rumen Ammonia, pH, and VFA. The effects of $\mathrm{LF}$ on rumen $\mathrm{pH}$ and ruminal concentrations of $\mathrm{NH}_{3}-\mathrm{N}$ and VFA are presented in Table 5 . Ruminal $\mathrm{pH}$ was not affected $(P=0.64)$ by LF strategies relative to the $\mathrm{C} 100$ diet. Normal declines in postfeeding ruminal $\mathrm{pH}$ occurred $(P<0.01)$, but these changes in ruminal $\mathrm{pH}$ over time were similar $(P=0.80)$ across treatments. Ruminal $\mathrm{pH}$ decreased to approximately 6.0 at 3 to $6 \mathrm{~h}$ postfeed- 
Table 4. Effect of limit feeding on blood profiles of growing Holstein replacement heifers

\begin{tabular}{|c|c|c|c|c|c|c|}
\hline Item & \multicolumn{3}{|c|}{ Treatment $^{1,2}$} & SEM & \multicolumn{2}{|c|}{ Effect $(P>\mathrm{F})$} \\
\hline Glucose, $\mathrm{mg} / \mathrm{dL}$ & 68 & 73 & 75 & 2.1 & 0.03 & 0.50 \\
\hline Total protein, g/dL & 7.1 & 7.1 & 7.2 & 0.11 & 0.92 & 0.82 \\
\hline Albumin, $\mathrm{g} / \mathrm{dL}$ & 3.6 & 3.7 & 3.7 & 0.03 & 0.34 & 0.41 \\
\hline $\mathrm{BUN}, \mathrm{mg} / \mathrm{dL}$ & 14.2 & 16.8 & 16.1 & 1.12 & 0.14 & 0.69 \\
\hline
\end{tabular}

${ }^{1} \mathrm{C} 100=$ control diet; $\mathrm{L} 85=$ limited to $85 \%$ of $\mathrm{C} 100 ; \mathrm{L} 80+\mathrm{I}=$ limited to $80 \%$ of $\mathrm{C} 100+325 \mathrm{mg} / \mathrm{d}$ of lasalocid.

${ }^{2}$ Mean values at $3 \mathrm{~h}$ postfeeding.

${ }^{3} \mathrm{C}=$ control $(\mathrm{C} 100)$ vs. $\mathrm{LF}=$ limit fed $(\mathrm{L} 85$ and $\mathrm{L} 80+\mathrm{I})$ diets.

ing for all treatment groups. These observations are similar to those in other studies (Gabler and Heinrichs, 2003; Moody et al., 2007; Lascano and Heinrichs, 2009) in which higher concentrate diets offered at restricted intakes did not markedly affect ruminal $\mathrm{pH}$. Rumen $\mathrm{NH}_{3}-\mathrm{N}$ was not different $(P \geq 0.56)$ among treatments, and no time $\times$ treatment interaction was observed $(P=$ $0.70)$. Acetate, propionate, and butyrate concentrations were not different among treatment groups $(P \geq 0.52)$. In this study, the $\mathrm{L} 80+\mathrm{I}$ feeding strategy did not reduce $(P=0.28)$ the acetate:propionate ratio relative to the L85 diet, nor did LF diets differ $(P=0.35)$ from C100. In this study, the inclusion of an ionophore resulted in only a numerical reduction in the acetate:propionate ratio; however, other researchers (Ricke et al., 1984; Wessels et al., 1996) have observed stronger responses. In general, the results of this study suggest that LF did not greatly affect ruminal VFA parameters, which agrees with previous work (Moody et al., 2007; Lascano and Heinrichs, 2009).

\section{Lactation Phase}

Dystocia and Calf $\boldsymbol{B} \boldsymbol{W}$. After calving, all cows were offered a common diet to assess potential carryover effects from diets offered during the growth phase of the study. Treatment groups for the lactation phase reflect diets offered during the growth phase, and are identified as such (C100, L85, or L80+I). Calf BW did not differ $(P=0.84)$ among treatment groups and averaged $40 \pm$ $4.5 \mathrm{~kg}$ (Table 6). These data support the observations of Hoffman et al. (2007), who did not observe differences in calf BW or dystocia index when calves were born to heifers LF at 90 or $80 \%$ of ad libitum intake. In the current experiment, cows offered C100, L85, or L80+I diets as heifers exhibited low dystocia indices that did not differ $(P \geq 0.19)$ across treatments.

$\boldsymbol{B} \boldsymbol{W}$. Postpartum BW $(7 \mathrm{~d})$ and BW at 45 and 90 DIM for primiparous cows did not differ $(P \geq 0.38)$ among treatments, averaging $556 \mathrm{~kg}$. Changes in BW (loss or gain) observed in early lactation cows during this experiment were consistent with expectations based on changing energy balances during early lactation (NRC, 2001). Data suggest that LF strategies during the development of gravid heifers had little carryover effect on the BW of primiparous cows during early lactation. The BCS of primiparous cows at 45 and 90 DIM were likewise similar $(P \geq 0.13)$, suggesting that LF of heifers did not result in a carryover effect on BCS throughout early lactation.

DMI. Primiparous cow DMI did not differ among treatments at $45(P \geq 0.24)$ or 90 DIM $(P \geq 0.36)$. Dry matter intake of primiparous cows averaged 19.2 and

Table 5. Effect of limit feeding on concentrations of rumen $\mathrm{pH}, \mathrm{NH}_{3}-\mathrm{N}$, and volatile fatty acids

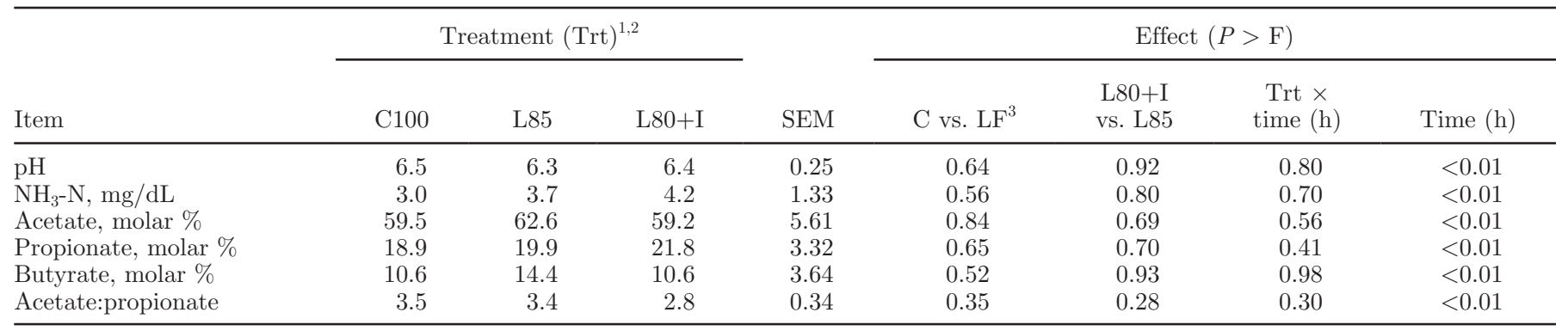

${ }^{1} \mathrm{C} 100=$ control diet; $\mathrm{L} 85=$ limited to $85 \%$ of $\mathrm{C} 100 ; \mathrm{L} 80+\mathrm{I}=$ limited to $80 \%$ of $\mathrm{C} 100+325 \mathrm{mg} / \mathrm{d}$ of lasalocid.

${ }^{2}$ Mean values for 2 consecutive days at $-1,1,3,6,9,12$, and $18 \mathrm{~h}$ postfeeding.

${ }^{3} \mathrm{C}=$ control $(\mathrm{C} 100)$ vs. $\mathrm{LF}=$ limit fed $(\mathrm{L} 85$ and $\mathrm{L} 80+\mathrm{I})$ diets. 
Table 6. Effect of limit feeding on postpartum BW, calf BW, dystocia, and DMI

\begin{tabular}{|c|c|c|c|c|c|c|}
\hline Item & \multicolumn{3}{|c|}{ Treatment $^{1}$} & SEM & \multicolumn{2}{|c|}{ Effect $(P>\mathrm{F})$} \\
\hline $\mathrm{BW}(7 \mathrm{~d}), \mathrm{kg}$ & 561 & 573 & 565 & 9.2 & 0.51 & 0.51 \\
\hline Calf BW, kg & 40.8 & 40.7 & 40.5 & 0.92 & 0.84 & 0.91 \\
\hline Dystocia index ${ }^{3}$ & 0.5 & 1.0 & 0.8 & 0.21 & 0.19 & 0.54 \\
\hline DMI, kg & 19.5 & 19.5 & 18.7 & 0.49 & 0.56 & 0.24 \\
\hline DMI, $\%$ of BW & 3.6 & 3.7 & 3.6 & 0.09 & 0.94 & 0.52 \\
\hline Feed efficiency, $\mathrm{kg}$ of milk/kg of DMI & 1.7 & 1.8 & 1.8 & 0.06 & 0.63 & 0.76 \\
\hline \multicolumn{7}{|l|}{90 DIM } \\
\hline $\mathrm{BW}, \mathrm{kg}$ & 563 & 562 & 552 & 8.3 & 0.58 & 0.38 \\
\hline $\mathrm{BCS}$ & 2.8 & 2.8 & 2.8 & 0.07 & 0.76 & 0.86 \\
\hline
\end{tabular}

${ }^{1} \mathrm{C} 100=$ control diet; $\mathrm{L} 85=$ limited to $85 \%$ of $\mathrm{C} 100 ; \mathrm{L} 80+\mathrm{I}=$ limited to $80 \%$ of $\mathrm{C} 100+325 \mathrm{mg} / \mathrm{d}$ of lasalocid.

${ }^{2} \mathrm{C}=$ control $(\mathrm{C} 100)$ vs. $\mathrm{LF}=$ limit fed $(\mathrm{L} 85$ and $\mathrm{L} 80+\mathrm{I})$ diets.

${ }^{3}$ Five-point scale, where $0=$ no difficulties to $3+=$ needed assistance; Hoffman et al., 2007.

${ }^{4}$ Five-point scale, where $1=$ thin to $5=$ obese; Wildman et al., 1982.

$20.5 \mathrm{~kg} / \mathrm{d}$ at 45 and 90 DIM, respectively, which ranged from 3.6 to $3.8 \%$ of BW. Lactation feed efficiency ( $\mathrm{kg}$ of milk $/ \mathrm{kg}$ of feed) was similar $(P \geq 0.17)$ for primiparous cows offered LF diets as heifers compared with those offered C100 diets. These results suggest that the LF strategies evaluated in this trial for gravid heifers had no appreciable carryover effects on DMI or feed utilization efficiency during subsequent early lactation.

Lactation Performance. The effects of LF during the heifer growth trial on subsequent postpartum lactation performance are presented in Table 7. Limit feeding gravid heifers before calving had no effect $(P \geq$ $0.28)$ on milk production at 45 or 90 DIM. These data are consistent with findings from Zanton and Heinrichs (2007) and Hoffman et al. (2007). Zanton and Heinrichs (2007) noted that milk yield tended to be greater from cows offered LF high-concentrate diets as heifers compared with those offered high-forage diets. The lack of effects on milk production observed in our study suggests that milk yield is neither increased nor decreased as a result of LF before parturition. Percentages of milk fat and milk protein and their respective yields did not differ $(P \geq 0.12)$ among treatment groups at 45 and 90 DIM. Overall, milk fat averaged $3.8 \%$ at 45 DIM and decreased to $3.5 \%$ at 90 DIM, whereas milk protein concentrations remained stable at $2.9 \%$ across both evaluation periods. Lactose and solids-not-fat (\%) also did not differ $(P \geq 0.19)$ among treatment groups.

Digesta Volume and Density. Rumen digesta volume of cannulated heifers was not different $(P \geq$ 0.34) among treatments during the growth phase or postgrowth trial when heifers were offered a common
high-NDF diet (Table 8). Mean growth-phase rumen digesta volumes were numerically greater for LF heifers (98.4 L) compared with heifers offered the $\mathrm{C} 100$ diet $(86.3 \mathrm{~L})$. When heifers were immediately switched to a common high-NDF diet after the growth phase, rumen volumes for LF and C100 heifers were 93.0 and $81.0 \mathrm{~L}$, respectively. Rumen volumes at 45 and 90 DIM also did not differ $(P \geq 0.33)$ between primiparous cows offered $\mathrm{LF}$ and $\mathrm{C} 100$ diets as heifers. However, cows offered the L80+I diet as heifers did exhibit less $(P=0.01)$ rumen volume $(66.1 \mathrm{~L})$ than cows offered the $\mathrm{L} 85$ diet as heifers $(99.1 \mathrm{~L})$. Differences in rumen volume at 45 DIM for cows offered the L85 and L80+I diets as heifers are challenging to explain. No supportive measurements within the trial corroborate these observations. Cows offered the L80+I diet as heifers exhibited similar DMI, milk yield, and yields of milk components at 45 DIM compared with cows offered the L85 diet as heifers. Cows offered the L80+I diet as heifers did not display lower rumen volume during the growth trial or during the posttrial period when heifers were offered a common high-NDF diet. There are no data in the literature to suggest that feeding an ionophore to heifers results in a carryover effect on rumen volume during early lactation.

Rumen digesta volume (L) expressed per kilogram of BW was not different between LF heifers and heifers offered the $\mathrm{C} 100$ diet during the growth trial $(P=$ $0.31)$, posttrial $(P=0.39)$, and at 45 or 90 DIM $(P \geq$ $0.27)$. Likewise, rumen digesta density did not differ $(P \geq 0.06)$ between treatments during any phase of the project. Rumen digesta volume and density gen- 
Table 7. Effect of limit feeding on postpartum lactation performance

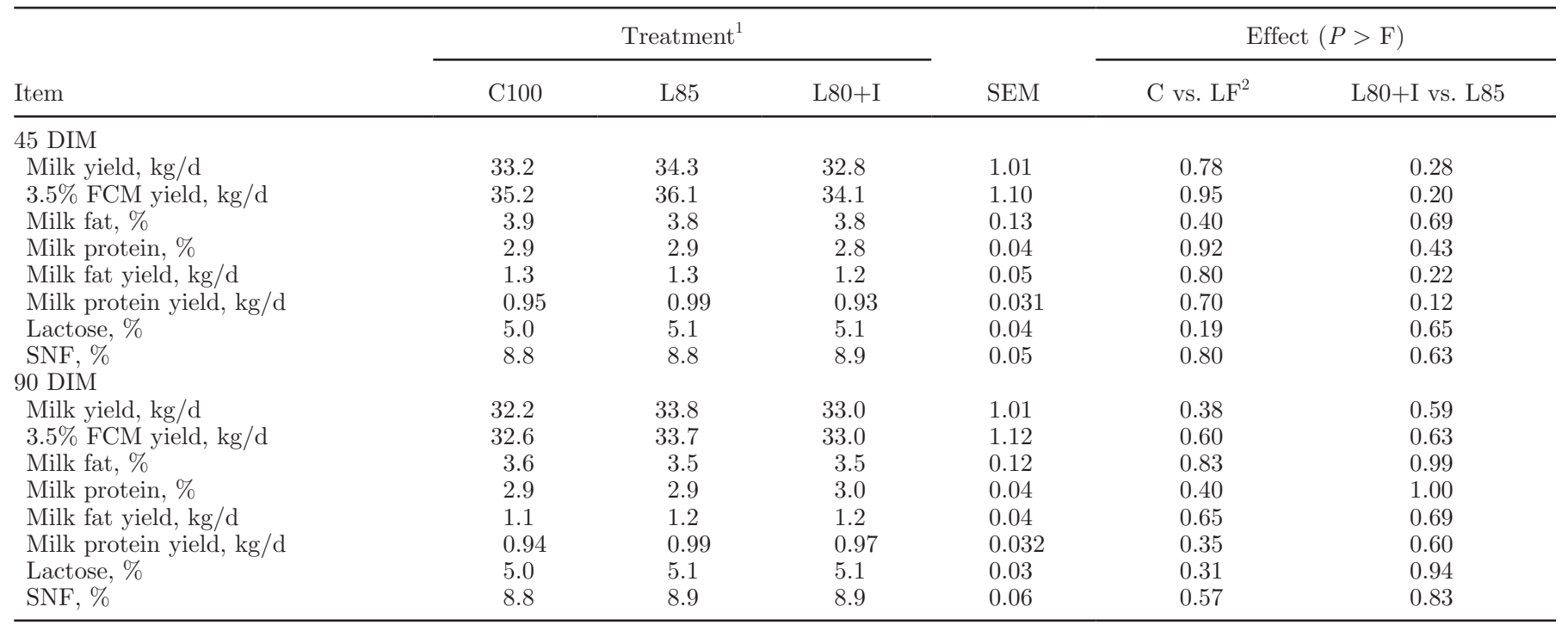

${ }^{1} \mathrm{C} 100=$ control diet; $\mathrm{L} 85=$ limited to $85 \%$ of $\mathrm{C} 100 ; \mathrm{L} 80+\mathrm{I}=$ limited to $80 \%$ of $\mathrm{C} 100+325 \mathrm{mg} / \mathrm{d}$ of lasalocid.

${ }^{2} \mathrm{C}=$ control $(\mathrm{C} 100)$ vs. $\mathrm{LF}=$ limit fed $(\mathrm{L} 85$ and $\mathrm{L} 80+\mathrm{I})$ diets.

erally have an inverse relationship, and the variation in rumen digesta density was minimal among all rumen evacuation periods. Split-plot analysis (data not shown) of rumen digesta volume (L), volume (L/ $\mathrm{kg}$ of $\mathrm{BW})$, density $(\mathrm{kg} / \mathrm{L})$, wet digesta weight $(\mathrm{kg} / 500 \mathrm{~kg}$ of BW) and dry digesta weight $(\mathrm{kg} / 500 \mathrm{~kg}$ of BW) by time (trial, posttrial, 45 DIM, 90 DIM) likewise did not elicit carryover effects associated with LF.

\section{CONCLUSIONS}

The primary objective of this experiment was to evaluate potential carryover effects associated with limit feeding gravid dairy heifers. As observed in previous research, LF strategies improved ADG and feed:gain ratios, and had no effect on rumen fermentation parameters. Limit feeding gravid Holstein heifers for $180 \mathrm{~d}$ did

Table 8. Effect of limit feeding heifers on 3-h postfeeding rumen digesta volume during the growth phase, posttrial, and during lactation

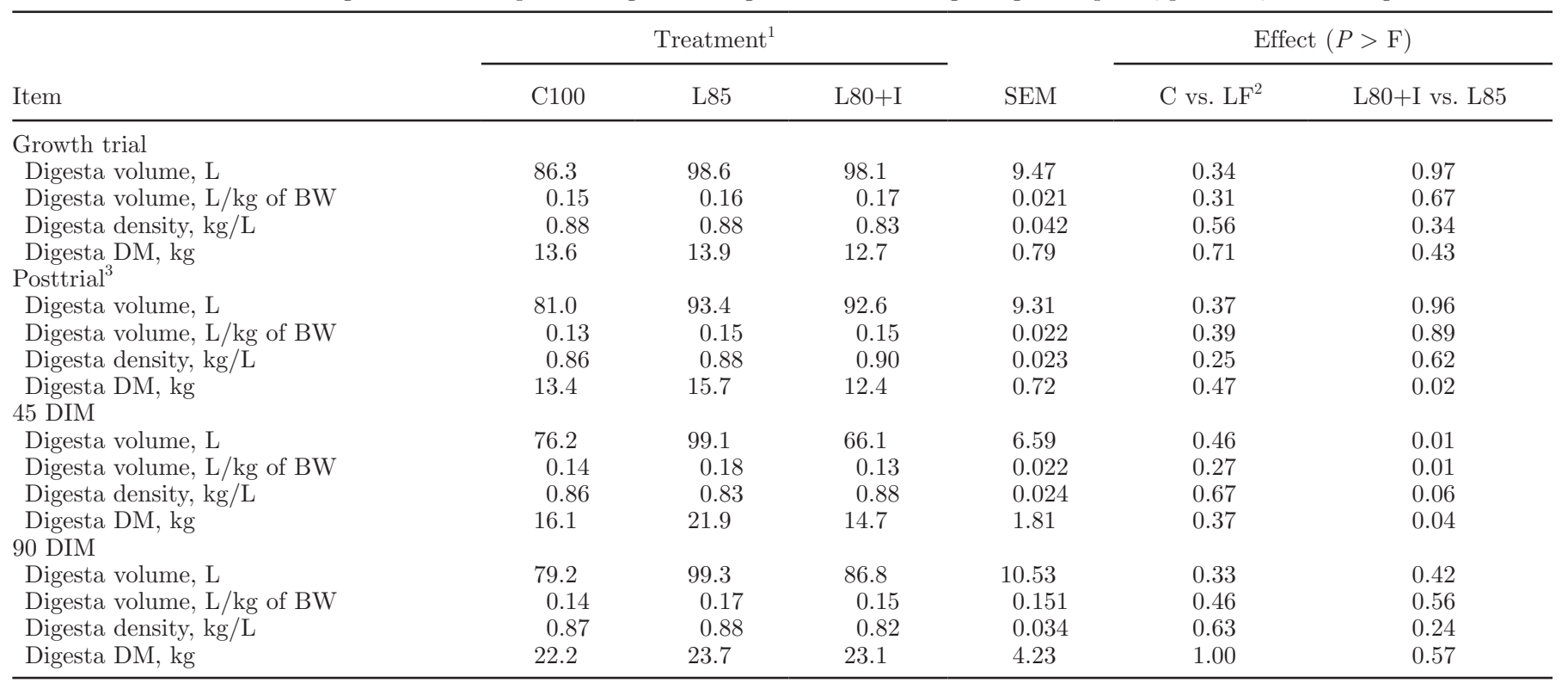

${ }^{1} \mathrm{C} 100=$ control diet; $\mathrm{L} 85=$ limited to $85 \%$ of $\mathrm{C} 100 ; \mathrm{L} 80+\mathrm{I}=$ limited to $80 \%$ of $\mathrm{C} 100+325 \mathrm{mg} / \mathrm{d}$ of lasalocid.

${ }^{2} \mathrm{C}=$ control $(\mathrm{C} 100)$ vs. $\mathrm{LF}=$ limit fed $(\mathrm{L} 85$ and $\mathrm{L} 80+\mathrm{I})$ diets.

${ }^{3}$ Posttrial heifers were fed a common high-forage diet (C100). 
not affect calf BW, dystocia index, or 7-d postpartum BW. Postpartum DMI, BW, BCS, milk yield, and milk composition were unaffected when cows were LF as heifers. Ruminal digesta volume was similar when heifers were switched to a common high-NDF diet during a posttrial evaluation period, and LF did not conclusively affect rumen volume during early lactation. Limit feeding gravid Holstein heifers for $180 \mathrm{~d}$ did not result in appreciable carryover effects following parturition.

\section{ACKNOWLEDGMENTS}

This manuscript is based upon research supported by federal Hatch funds and the College of Agriculture and Life Sciences, University of Wisconsin, Madison. This study was also financially supported through unrestricted gifts from Alpharma (Elizabeth, NJ) and Eastland Feed and Grain (Shannon, IL). The authors acknowledge Lance Fox of Alpharma for his contributions and unconditional support of this project and Richard Straub of the College of Agriculture and Life Sciences for his leadership and foresight in program development at the Integrated Dairy Research Facility at the University of Wisconsin-Madison.

\section{REFERENCES}

Association of Official Analytical Chemists. 1990. Official Methods of Analysis. 15th ed. AOAC, Arlington, VA

Bal, M. A., R. D. Shaver, A. G. Jirovec, K. J. Shinners, and J. G. Coors. 2000. Crop processing and chop length of corn silage: Effects on intake, digestion, and milk production by dairy cows. J. Dairy Sci. 83:1264-1273

Chester-Jones, H., J. G. Linn, D. M. Ziegler, and M. A. Engstrom. 1997. Determination of the caloric equivalency of an ionophore in dairy heifer diets. J. Dairy Sci. 80(Suppl. 1):216. (Abstr.)

Esser, N. M., P. C. Hoffman, W. K. Coblentz, M. W. Orth, and K. A Weigel. 2009. The effect of dietary phosphorus on bone development in dairy heifers. J. Dairy Sci. 92:1741-1749.

Gabler, M. T., and A. J. Heinrichs. 2003. Effects of increasing dietary protein on nutrient utilization in heifers. J. Dairy Sci. 86:21702177.

Goering, H. K., and P. J. Van Soest. 1970. Pages 8-11 in Forage Fiber Analyses (Apparatus, Reagents, Procedures, and Some Applications). Agric. Handbook No. 379. ARS-USDA, Washington, DC.

Hicks, R. B., F. N. Owens, D. R. Gill, J. J. Martin, and C. A. Strasia. 1990. Effects of a controlled feed intake on performance and carcass characteristics of feedlot steers and heifers. J. Anim. Sci. 68:233-244.

Hoffman, P. C., C. R. Simson, and M. Wattiaux. 2007. Limit feeding of gravid Holstein heifers: Effect on growth, manure nutrient excretion and subsequent early lactation performance. J. Dairy Sci. 90:946-954.

Hoffman, P. C., K. A. Weigel, and R. M. Wernberg. 2008. Evaluation of equations to predict dry matter intake of dairy heifers. J. Dairy Sci. 91:3699-3709

Johnson, T. R., and D. K. Combs. 1991. Effects of prepartum diet, inert rumen bulk, and dietary polyethylene glycol on dry matter intake of lactating dairy cows. J. Dairy Sci. 74:933-944.
Lascano, G. J., and A. J. Heinrichs. 2009. Rumen fermentation pattern of dairy heifers fed restricted amounts of low, medium, and high concentrate diets without and with yeast culture. Livest. Sci. 124:48-57.

Mertens, D. R. 1992. Critical conditions in determining detergent fibers. Page C-1 in Proc. Natl. Forage Testing Assoc. Forage Anal Workshop, Denver, CO. Natl. Forage Testing Assoc., Omaha, $\mathrm{NE}$

Moody, M. L., G. I. Zanton, J. M. Daubert, and A. J. Heinrichs 2007. Nutrient utilization of differing forage-to-concentrate ratios by growing Holstein heifers. J. Dairy Sci. 90:5580-5586.

Murphy, T. A., S. C. Loerch, and F. E. Smith. 1994. Effects of feeding high-concentrate diets at restricted intakes on digestibility and nitrogen metabolism in growing lambs. J. Anim. Sci. 72:15831590 .

NRC. 2001. Nutrient Requirements of Dairy Cattle. 7th Rev ed. Natl. Acad. Sci., Washington, DC.

Reynolds, C. K., H. F. Tyrrell, and P. J. Reynolds. 1991. Effects of diet forage-to-concentrate ration and intake on energy metabolism in growing beef heifers: Net nutrient metabolism by visceral tissues. J. Nutr. 121:1004-1015.

Ricke, S. C., L. L. Berger, P. J. van der Aar, and G. C. Fahey Jr. 1984. Effects of lasalocid and monensin on nutrient digestion, metabolism and rumen characteristics of sheep. J. Anim. Sci $58: 194-202$

Roberts, A. J., S. I. Paisley, T. W. Geary, E. E. Grings, R. C. Waterman, and M. D. MacNeil. 2007. Effects of restricted feeding of beef heifers during the postweaning period on growth, efficiency, and ultrasound carcass characteristics. J. Anim. Sci. 85:2740-2745.

SAS Institute. 2003. SAS User's Guide: Statistics. Version 9.1 Edition. SAS Inst. Inc., Cary, NC.

Schulte, E. E., J. B. Peters, and P. R. Hodgson. 1987. Wisconsin procedures for soil testing, plant analysis and feed and forage analysis. Dept. Soil Sci. Bull. No. 6. University of Wisconsin, Madison.

Sievert, S. J., and R. D. Shaver. 1993. Carbohydrate and Aspergillus oryzae: Effects on intake, digestion, and milk production by dairy cows. J. Dairy Sci. 76:245-254.

Sip, M. L., and R. H. Pritchard. 1991. Nitrogen utilization by ruminants during restricted intake of high-concentrate diets. J. Anim. Sci. 69:2655-2662.

St-Pierre, N. R. 2007. Design and analysis of pen studies in the animal sciences. J. Dairy Sci. 90(E. Suppl.):E87-E99.

Susin, I., S. C. Loerch, K. E. McClure, and M. L. Day. 1995. Effects of limit-feeding a high grain diet on puberty and reproductive performance of ewes. J. Anim. Sci. 73:3206-3215.

Van Soest, P. J., J. B. Robertson, and B. A. Lewis. 1991. Methods for dietary fiber, neutral detergent fiber, and nonstarch polysaccharides in relation to animal nutrition. J. Dairy Sci. 74:3583-3597.

Varel, V. H., J. A. Nienaber, and H. C. Freetly. 1999. Conservation of nitrogen in cattle feedlot waste with urease inhibitors. J. Anim. Sci. 77:1162-1168

Wessels, R., E. C. Titgemeyer, C. K. Armendariz, and G. St. Jean 1996. Lasalocid effects on ruminal degradation of protein and postruminal supply of amino acids in Holstein steers. J. Dairy Sci. 79:1802-1808

Wildman, E. E., G. M. Jones, P. E. Wagner, R. L. Boman, H. F. Troutt Jr., and T. N. Lesch. 1982. A dairy cow body condition scoring system and its relationship to selected production characteristics. J. Dairy Sci. 65:495-501.

Zanton, G. I., and A. J. Heinrichs. 2007. The effects of controlled feeding of a high-forage or high-concentrate ration on heifer growth and first-lactation milk production. J. Dairy Sci. 90:3388-3396.

Zanton, G. I., and A. J. Heinrichs. 2008. Rumen digestion and nutritional efficiency of dairy heifers limit-fed a high forage ration to four levels of dry matter intake. J. Dairy Sci. 91:3579-3588.

Zanton, G. I., and A. J. Heinrichs. 2009. Digestion and nitrogen utilization in dairy heifers limit-fed a low or high forage ration at four levels of nitrogen intake. J. Dairy Sci. 92:2078-2094. 